\title{
EPIDEMIOLOGICAL INVESTIGATION ON DUCK SALMONELLOSIS IN SOME SELECTED AREAS OF BANGLADESH
}

\author{
R. K. Dey ${ }^{1}$, M. S. R. Khan ${ }^{1}$, K. H. M. N. H. Nazir ${ }^{1 *}$, M. A. Islam ${ }^{1}$ and S. M. S. H. Belal ${ }^{2}$ \\ ${ }^{1}$ Department of Microbiology and Hygiene, Bangladesh Agricultural University, Mymensingh-2202, \\ Bangladesh; ${ }^{2}$ Veterinary Surgeon, District Veterinary Hospital, Sirajgonj, Bangladesh
}

\begin{abstract}
The study was performed with a view to collect epidemiological data to proper control of duck salmonellosis in Bangladesh. A total of 12 small to medium sized duck farms and 28 individual households were visited for data collection. On the basis of history and clinical signs and as per the information provided by the farmers the prevalence rate of duck salmonellosis was recorded as $38.1 \%$ and the $P$ value was calculated as $0.003(\mathrm{p}<0.01)$ which was noted as highly significant. Based on tentative occurrences of duck salmonellosis as per information taken from the structured questionnaire a total of 120 fecal samples were collected from apparently healthy and diseased ducks on the basis of age, sex, season, location and health status. The isolated bacteria were identified by studying cultural properties on different selective media, biochemical tests, and finally by PCR. The test results of cultural and biochemical exhibited the typical characteristics of bacteria. On the basis of their cultural and biochemical characteristics it was found that among 120 fecal samples $32(26.67 \%)$ were found to be positive for Salmonella and the $P$ value was recorded as 0.0019 ( $<<0.01)$ which was also considered as highly significant. In motility test duck Salmonella were identified as motile and all tested duck Salmonella showed indole and VP test negative with MR test positive. In PCR reaction, the organism was further confirmed as Salmonella species using the SAL-G primer. Results of antibiotic susceptibility test shows that the selected isolated Salmonella were highly sensitive to ciprofloxacin and azithromycin, intermediate sensitive to tobramycin and gentamicin and resistant to oxacillin.
\end{abstract}

Key words: Salmonellosis, $16 \mathrm{~S}$ rRNA gene, prevalence

\section{INTRODUCTION}

Duck salmonellosis is a disease of economic importance which occurs sporadically or enzootically all over Bangladesh. Mortality may vary from $10 \%$ to $80 \%$ or higher in severe outbreaks (Kumar and Kaushi, 1988; Kaura et al., 1990; Kleven and Yoder, 1998). Duck salmonellosis is mainly caused by many types of Salmonella species. As a species next to chicken, duck production plays a significant role in the rural economy of Bangladesh. It contributes a major source of animal protein in Bangladesh. Ducks are mainly reared in waterlogged areas of Bangladesh such as Netrokona, Kishoregonj, Brahmanbaria, Habigonj, Habiganj, Gaibandha, Noakhali, Mymensingh. Huque and Sultana (2002) reported that natural water areas in different districts of Bangladesh vary from 151 to 12731 hectares.

But there are many obstacles for the establishment of large scale duck farming both in rural and urban area of Bangladesh. The reasons of mortality of duck in Bangladesh are Bird flu, duck plague, duck viral hepatitis, duck cholera, duck salmonella, duck septicemia, mycoplasmosis-colibacillosis complex, tapeworm infestation, fluke infestation, heat stroke, and ascariasis (Sarkar 1980, 1982; Mustafa et al., 1985; Baki et al., 1986; Das et al., 2005; Islam et al., 2007; Haque et al., 2011; Nooruzzaman et al., 2012). Including several numbers of infectious diseases Duck Salmonellosis has been considering is a major disease, hampering the duck industry throughout the world. Price and Berry (1962) have shown that Salmonella anatum, is the most important infectious agent in case of Duck Salmonellosis. Others related species were Salmonella enteritidis, Salmonella bredeney, Salmonella panama, Salmonella give, Salmonella senftenberg, Salmonella newport, Salmonella oregon, Salmonella saintpaul, Salmonella manhattan and Salmonella manchester.

The members of the genus Salmonella were identified by studying cultural properties on different selective media such as selenite broth, Salmonella-Shigella (SS) agar, XLD agar, MacConkey agar, Brilliant green agar (BGA); biochemical tests, and finally by PCR. Antibiogram study, serum agglutination test and PCR (Polymerase chain reaction) are widely being used to identify and characterize Salmonella species in the laboratories (Deighan et al., 2000; Veling et al., 2000; Buerfeind et al., 2001). Salmonella organisms were isolated from various hosts such as from chickens (Begum, 1992), cattle (Islam, 2007), goat (Rahman, 2006), sheep (Karim, 2007) and other animals in Bangladesh and from chicks of Japan by Begum in 2005.

*Corresponding e-mail address: nazir@bau.edu.bd 


\section{R. K. Dey and others}

Although a few research works were done on the basis of this topic internationally but nationally there is no research work was done related to the mentioned title. So, the present work was undertaken to study the prevalence of Duck Salmonellosis considering age, sex, season and location; to isolate and characterize the etiological agent of Duck Salmonella from the collected sample from apparently healthy and diseased Ducks through agent surveillance using cultural, biochemical and molecular technique and to study the antibiogram of the selected isolated species of Duck Salmonella species.

\section{MATERIALS AND METHODS}

\section{Sample collection}

At first the epidemiological data and subsequently cloacal swab samples were collected from Mohongonj of Netrokona, Tarail of Kishoregonj, Chunarughat of Habiganj, Ramgonj of Lakshmipur and Phulpur of Mymensingh, Bangladesh. A total number of 120 field samples (cloacal swab) from apparently healthy and diseased ducks. The samples were collected from April 2014 to March 2015 and investigation was carried out following collection. The samples were aseptically collected and then these samples were carried to the Bacteriology Laboratory at the Department of Microbiology and Hygiene of BAU, Mymensingh through Nutrient broth for bacteriological analysis.

\section{Epidemiological investigation on Duck Salmonellosis}

Epidemiological data and cloacal swab were collected from selected areas of Netrokona, Kishoregonj, Habiganj, Lakshmipur and Mymensingh districts of Bangladesh. Epidemiological data were collected through structured Questionnaire and epidemiological investigation was carried out based on some epidemiological parameters such as age, sex, seasons, location and health status of the ducks followed by isolation, identification, molecular characterization and antibiogram study of Duck Salmonella bacteria (Table 1 and Table 2).

Table 1. Number of cloacal swab samples collected from apparently healthy and diseased ducks of Mymensingh, Netrokona, Habiganj, Kishoregonj and Lakshmipur

\begin{tabular}{c|c|c}
\hline Sl. No. & Study areas & Number of Cloacal Swabs collected \\
\hline 1. & Mymensingh & 32 \\
\hline 2. & Lakshmipur & 24 \\
\hline 3. & Kishorgonj & 16 \\
\hline 4. & Netrokona & 22 \\
\hline 5. & Habiganj & 26 \\
\hline & Total & 120 \\
\hline
\end{tabular}

Table 2. Summary of cloacal samples collected from duck based on age, sex, season and health status

\begin{tabular}{|c|c|c|c|c|c|}
\hline $\begin{array}{l}\text { Sl. } \\
\text { No. }\end{array}$ & $\begin{array}{c}\text { Epidemiological } \\
\text { parameters }\end{array}$ & Level of patterns & $\begin{array}{c}\text { Apparently } \\
\text { healthy }\end{array}$ & Sick & $\begin{array}{c}\text { Number of animal } \\
\text { examined }\end{array}$ \\
\hline \multirow[t]{2}{*}{1.} & \multirow[t]{2}{*}{ Age } & $1-12$ month & 44 & 28 & 72 \\
\hline & & 13-24 month & 44 & 04 & 48 \\
\hline \multirow[t]{2}{*}{2.} & \multirow[t]{2}{*}{ Sex } & Male & 36 & 2 & 38 \\
\hline & & Female & 52 & 30 & 82 \\
\hline \multirow[t]{3}{*}{3.} & \multirow[t]{3}{*}{ Season } & Summer & 32 & 13 & 45 \\
\hline & & Rainy & 26 & 12 & 38 \\
\hline & & Winter & 30 & 7 & 37 \\
\hline \multirow[t]{2}{*}{4.} & \multirow[t]{2}{*}{ Health status } & \multicolumn{3}{|c|}{ Apparently healthy } & 88 \\
\hline & & \multicolumn{3}{|c|}{ Sick } & 32 \\
\hline
\end{tabular}


Epidemiological investigation on duck salmonellosis

\section{Isolation and identification of Salmonella}

Cloacal swabs were collected and each of swabs was inoculated into freshly prepared Nutrient broth. Then the tubes were marked properly and incubated at $37^{\circ} \mathrm{C}$ for 24 hours aerobically in bacteriological incubator. The incubated tubes were then examined for growth of bacteria. Smears were prepared from each of the test tubes and the smears were fixed. The fixed smears were stained with Gram's Method of staining and examined under microscope at 100 magnifications using immersion oil. In presence of gram negative rods in the smears, the materials from the tube corresponding to the smears were streaked onto MacConkey agar, SalmonellaShigella agar and Brilliant green agar separately. The plates were then incubated at $37^{\circ} \mathrm{C}$ for 24 hours and the plates containing characteristic colonies of Salmonella were selected. Motility test and Gram's staining test were performed to identify the plates containing Salmonella accurately. Sub culturing on Salmonella-Shigella agar was performed from the suspected plates containing Salmonella to obtain a pure culture. (Cheesbrough, 1985). Further the isolates were confirmed by amplification of Salmonella species specific $16 S r R N A$ gene.

\section{Bacterial Genomic DNA extraction}

A pure bacterial colony of Salmonella species was mixed with $200 \mu \mathrm{L}$ of distilled water which were boiled for 10 minutes then immediately kept on ice for cold shock. Finally centrifugation was done at $10000 \mathrm{rpm}$ for 10 minutes. The supernatant were collected and used as DNA template for PCR.

\section{Identification of Salmonella by PCR}

PCR reaction was performed to detect Salmonella species specific 16S rRNA gene from isolated Salmonella in a thermal cycler. Two different primers pairs were used for this purpose, 165 rRNA gene (F 5'ACTGGCGTTATCCCTTTCTCTGGTG -3' and R 5'-ATGTTGTCCTGCCCCTGGTAAGAGA-3') according to the methods described by Noah et al., 1993. Each $20 \mu 1$ reaction mixture consists of $3 \mu$ l genomic DNA, $10 \mu 1$ PCR master mixtures (Promega, USA), and $1 \mu 1$ of each of the two primers with the final volume adjusted to 20 $\mu 1$ with $5 \mu 1$ of nuclease free water. Amplification was done by initial denaturation at $94^{\circ} \mathrm{C}$ for 3 minutes, followed by denaturation at $94^{\circ} \mathrm{C}$ for $30 \mathrm{sec}$, annealing temperature of primers was $60^{\circ} \mathrm{C}$ for $60 \mathrm{sec}$ and extension at $72^{\circ} \mathrm{C}$ for $45 \mathrm{sec}$. The final extension was conducted at $72^{\circ} \mathrm{C}$ for 10 minutes. The total reaction was performed at 30 cycles. The amplified PCR products were resolved by electrophoresis in $2 \%$ agarose gel at $100 \mathrm{v}$ for 30 minutes, stained with ethidium bromide and finally visualized under UV trans-illuminator.

\section{Antibiotic Sensitivity Test}

A total of 5 Positive isolates were tested for antimicrobial drug susceptibility against five commonly used antibiotics by disc diffusion method (Bauer et al., 1966). Sensitivity pattern of the isolates were determined against oxacillin, gentamicin, tobramycin, azithromycin and ciprofloxacin. Antimicrobial testing results were recorded as sensitive, intermediate sensitive and resistant according to zone diameter interpretative standards provided by CLSI, 2012.

\section{RESULTS AND DISCUSSION}

The present study was performed for epidemiological investigation of Duck Salmonellosis in some selected areas of Bangladesh followed by isolation, identification and antibiogram study of Salmonella species. For this purpose at first data were collected through structured questionnaire. After consideration of collected data a total of 120 cloacal swab samples were collected and subjected to various cultural, biochemical's, molecular examinations and antibiogram study. The prevalence rate of Duck Salmonellosis from different location was shown in Table 3. Prevalence rate was recorded as $40.2 \%$ at farm level and 36\% was recorded as household level. Overall prevalence rate was recorded as $38.1 \%$ and the $P$ value was calculated as 0.003 ( $\mathrm{p}<0.01)$ which was noted as highly significant. 


\section{R. K. Dey and others}

Table 3. Demonstration of Prevalence rate of Duck Salmonellosis as per collected data considering the epidemiological parameters and clinical signs

\begin{tabular}{|c|c|c|c|c|c|c|c|c|c|c|c|}
\hline Location & 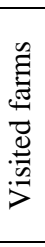 & 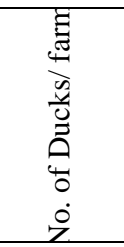 & 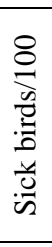 & $\begin{array}{l}\frac{8}{0} \\
\frac{0}{\pi} \\
\frac{\pi}{D} \\
0\end{array}$ & 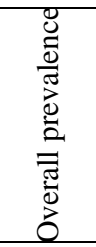 & $\begin{array}{l}0 \\
\frac{0}{0} \\
\frac{0}{0} \\
0 \\
0 \\
0\end{array}$ & 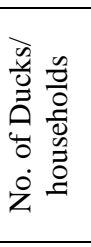 & 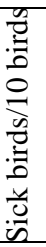 & $\begin{array}{l}\frac{8}{0} \\
\frac{0}{\pi} \\
\frac{\pi}{D} \\
D\end{array}$ & 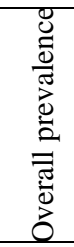 & Clinical signs \\
\hline Mymensingh & 3 & $101-500$ & 38 & $38 \%$ & \multirow{5}{*}{$40.2 \%$} & 7 & $2-20$ & 3 & $30 \%$ & \multirow{5}{*}{$36 \%$} & \multirow{5}{*}{$\begin{array}{l}\text { Whitish to straw } \\
\text { colored diarrhoea } \\
\text { Weight loss } \\
\text { Reduced production } \\
\text { Ruffled feathers }\end{array}$} \\
\hline Lakshmipur & 3 & $100-300$ & 37 & $37 \%$ & & 8 & $2-10$ & 4 & $40 \%$ & & \\
\hline Kishoregonj & 2 & $100-500$ & 42 & $42 \%$ & & 6 & $2-30$ & 4 & $40 \%$ & & \\
\hline Netrokona & 2 & $100-600$ & 44 & $44 \%$ & & 4 & $4-30$ & 4 & $40 \%$ & & \\
\hline Habiganj & 2 & $100-400$ & 40 & $40 \%$ & & 3 & $4-30$ & 3 & $30 \%$ & & \\
\hline \multicolumn{5}{|c|}{ Overall prevalence } & \multicolumn{7}{|c|}{$38.1 \%$} \\
\hline \multicolumn{5}{|c|}{$\mathrm{P}$ value } & \multicolumn{7}{|c|}{$0.003 * *$} \\
\hline
\end{tabular}

**means $1 \%$ level of sig. $(\mathrm{p}<0.01)$

Farms were classified as $1-50$ ducks $=$ Household duck keepers; $1-100$ ducks $=$ Small farms; $1-500=$ Medium farms and Over 500= Large farms

For this study the samples were collected on some epidemiological parameters such as age, sex, season, health status and location. The prevalence of Salmonella from different location was shown in Table $4 \& 5$, Figure $1 \&$ 2. Out of 120 samples examined 32 were found to be positive for Salmonella. Among the positive samples, 6 were from Mymensingh, 4 were from Lakshmipur, 9 were from Habiganj, 8 were from Netrokona and 5 were from Kishoregonj. The prevalence rate of Salmonella in Duck of these study areas were 18.75\%, 16.67\%, $34.61 \%, 36.36 \%, 31.25 \%$ respectively. Overall prevalence rate was $26.67 \%$. $P$ value was recorded as 0.0019 $(\mathrm{p}<0.01)$ which indicate that the result was highly significant.

Table 4. Results of isolation of Salmonella species from feces sample of apparently healthy and diseased ducks

\begin{tabular}{|c|c|c|c|c|c|}
\hline Study areas & $\begin{array}{c}\text { No of } \\
\text { collected } \\
\text { sample }\end{array}$ & $\begin{array}{l}\text { No. of positive } \\
\text { sample for } \\
\text { Salmonella }\end{array}$ & $\begin{array}{c}\text { Prevalence rate } \\
(\%)\end{array}$ & $\begin{array}{c}\text { Overall } \\
\text { prevalence rate } \\
(\%)\end{array}$ & $P$ value \\
\hline Mymensingh & 32 & 6 & $18.75 \%$ & \multirow{5}{*}{$26.67 \%(32 / 120)$} & \multirow{5}{*}{$0.0019 * *$} \\
\hline Lakshmipur & 24 & 4 & $16.67 \%$ & & \\
\hline Habiganj & 26 & 9 & $34.61 \%$ & & \\
\hline Netrokona & 22 & 8 & $36.36 \%$ & & \\
\hline Kishoregonj & 16 & 5 & $31.25 \%$ & & \\
\hline
\end{tabular}

** means $1 \%$ level of sig. $(\mathrm{p}<0.01)$ 


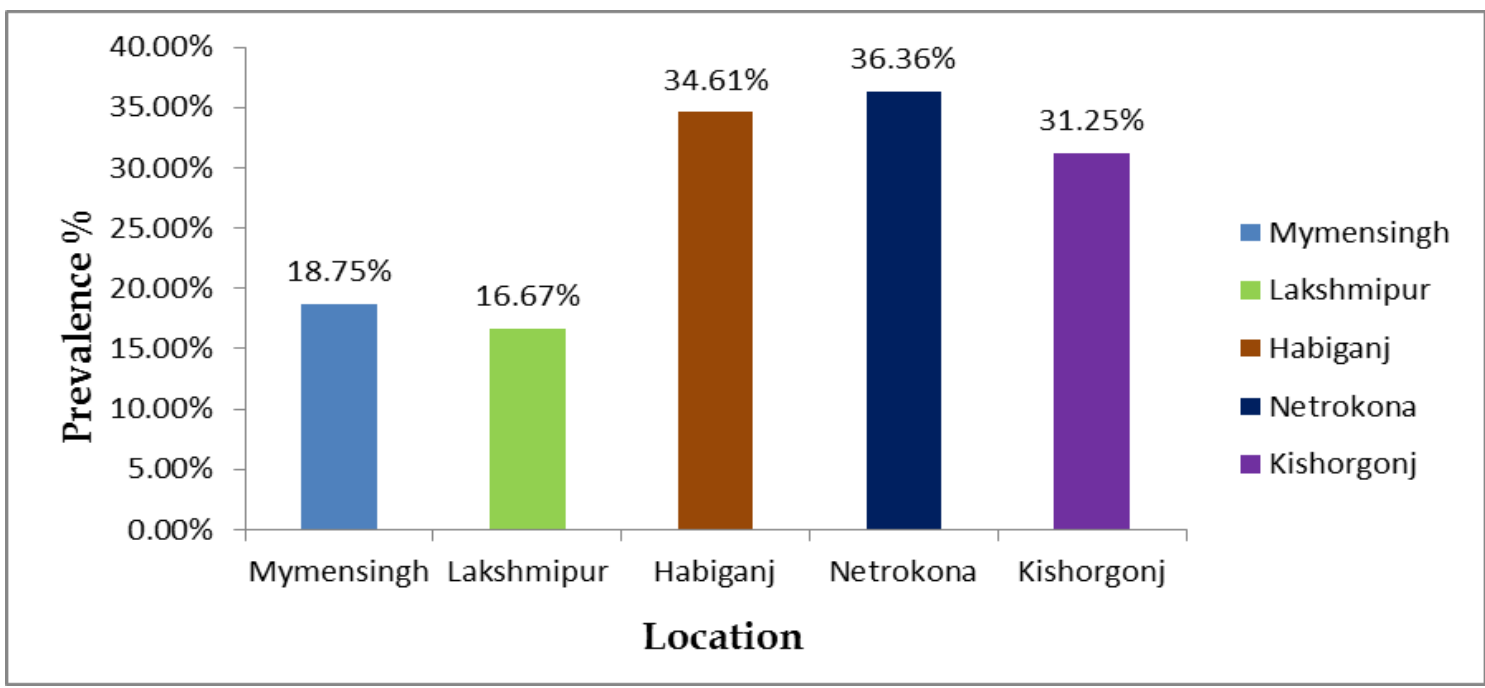

Figure 1. Graphical representation of the prevalence of Salmonella species at different locations (Results shown in table 4)

This figure represents that out of 120 samples $18.75 \%, 16.67 \%, 34.61 \%$, 36.36\% and 31.25\% were Salmonella positive at Memensingh, Lakshmipur, Habiganj, Netrokona and Kishoregonj respectively.

Table 5. Results of prevalence of Salmonella species at different epidemiological parameters

\begin{tabular}{|c|c|c|c|c|c|}
\hline $\begin{array}{c}\text { Epidemiological } \\
\text { parameters }\end{array}$ & Level of patterns & $\begin{array}{c}\text { No. of animal } \\
\text { examined }\end{array}$ & $\begin{array}{c}\text { No. of } \\
\text { Positive }\end{array}$ & Prevalence $(\%)$ & $P$ value \\
\hline \multirow{2}{*}{ Age } & $1-12$ month & 72 & 23 & 31.94 & \multirow[b]{2}{*}{$0.041^{*}$} \\
\hline & 13-24 month & 48 & 9 & 18.75 & \\
\hline \multirow[t]{2}{*}{ Sex } & Male & 38 & 4 & 10.52 & \multirow[b]{2}{*}{$0.004 *$} \\
\hline & Female & 82 & 28 & 34.14 & \\
\hline \multirow[t]{3}{*}{ Season } & Summer & 45 & 13 & 28.88 & \multirow{3}{*}{$0.001 * *$} \\
\hline & Rainy & 38 & 12 & 31.57 & \\
\hline & Winter & 37 & 7 & 18.92 & \\
\hline \multirow[t]{2}{*}{ Health status } & Apparently healthy & 88 & 7 & 7.95 & \multirow[b]{2}{*}{$0.007 * *$} \\
\hline & Sick & 32 & 25 & 78.12 & \\
\hline
\end{tabular}

* means $5 \%$ level of sig. $(\mathrm{p}<0.05)$

$* *$ means $1 \%$ level of sig. $(\mathrm{p}<0.01)$

This table represents that out of 120 samples prevalence of salmonellosis was $31.94 \%$ in 1 year aged ducks, $18.75 \%$ in more than 1 year aged ducks. $P$ value was calculated as $0.041(\mathrm{p}<0.05)$ that means the result was significant. Salmonellosis was $10.52 \%$ prevalent in male birds whereas $34.14 \%$ were in female; and the $P$ value was calculated as $0.004(\mathrm{p}<0.01)$ which indicate the result was highly significant. Salmonellosis was also prevalent $31.57 \%$ in Rainy season, $28.88 \%$ in summer and $18.92 \%$ in winter; and the $P$ value was calculated as $0.001(\mathrm{p}<0.01)$ that means the result was highly significant. At finally Salmonellosis was prevalent $78.12 \%$ in sick birds and $7.95 \%$ were in healthy ducks where $P$ value was calculated as $0.007(\mathrm{p}<0.01)$ which also indicate the result was highly significant. 


\section{R. K. Dey and others}

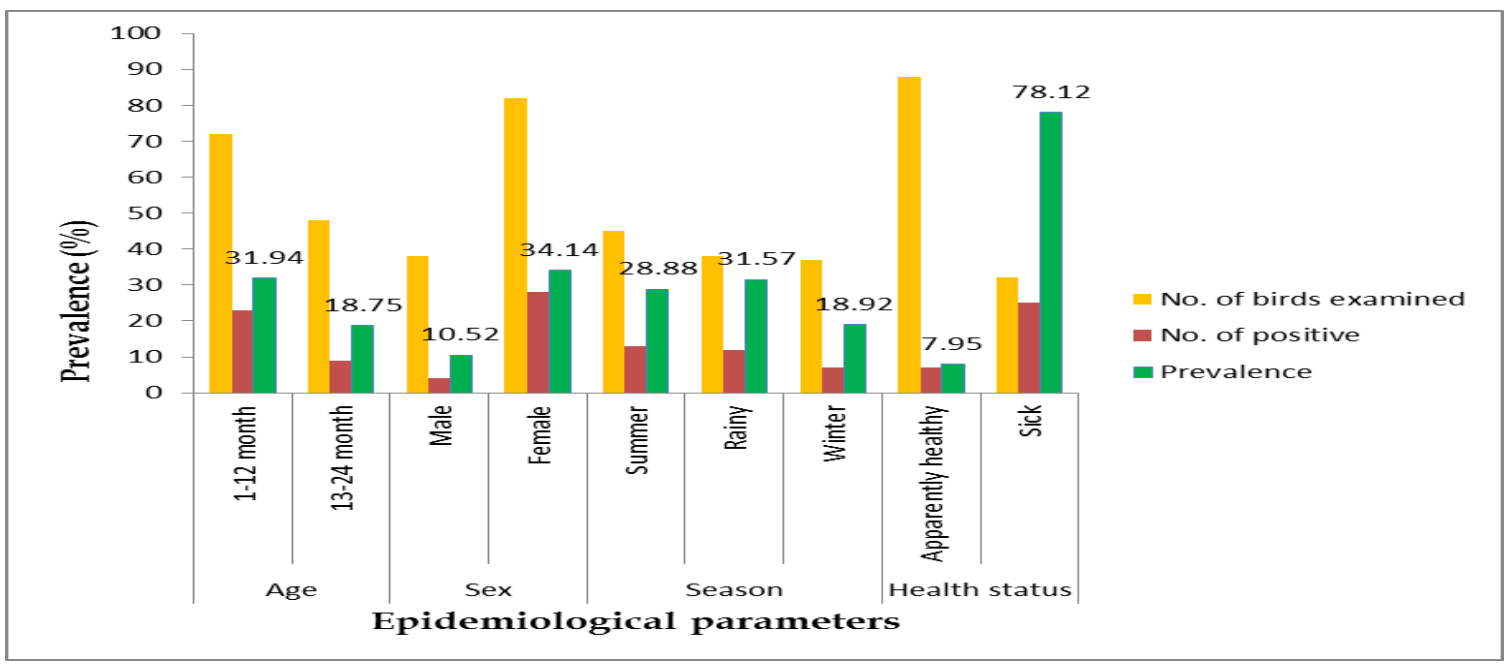

Figure 2. Graphical representation of prevalence rate of Salmonella according to age, sex, season and health status (Results shown in Table 5)

The collected swab samples were subjected to various cultural, biochemicals, molecular examinations and antibiogram study to identify and characterization of the isolates. In Nutrient broth the inoculated swab samples revealed the growth of bacteria after 24 hours of inoculation at $37^{\circ} \mathrm{C}$. The growth of bacteria was indicated by the presence of turbidity (Figure 3). On NA plates, the isolates produced round, smooth, opaque and translucent colonies (Figure 4). On SS agar plates, the isolates produced pinhead or lentil sized, raised, round or circular smooth, glistening, opaque, black, transparent or translucent colonies (Figure 5). On XLD agar plates, the isolates produced black centered colonies (Figure 6). On EMB agar plates, the isolates produced pink, smooth colonies (Figure 7). On blood agar isolates produced non hemolytic and gray colonies (Figure 8). On MC agar plates, the isolates produced colorless, smooth colonies (Figure 9). The microscopic examination of Gram's staining smears from SS, MC and BGA revealed short plum rod shaped organism, arranged in single and pairs (Figure 10). All of the isolates were found to be motile with hanging drop slide. The isolates were identified as Salmonella by biochemical test. All of the isolated Salmonella fermented dextrose, maltose, mannitol and dulcitol with the production of acid and gas but did not ferment lactose and sucrose. Acid production was indicated by the color change from reddish to yellow and gas production was noted by the presence of gas bubbles in the inverted Durham's tubes. These isolates were positive for MR test (development of red color indicated positive test) and negative for VP and Indole test. The optimized PCR assay was able to successfully amplify the target $16 \mathrm{~S}$ rRNA gene (496 bp fragment) from the DNA templates of all isolated Salmonella. Result of PCR for Salmonella is shown in Figure 11. The organism was subjected to antimicrobial susceptibility test by disc diffusion method against 5 most commonly used antimicrobial agents. From the antibiogram study, it was revealed that selected isolated of Mymensingh, Lakshmipur, Habiganj, Netrokona and Kishoregonj were highly sensitive to ciprofloxacin and azithromycin, moderately sensitive to gentamicin and tobramycin and were resistant to Oxacillin. 
Epidemiological investigation on duck salmonellosis

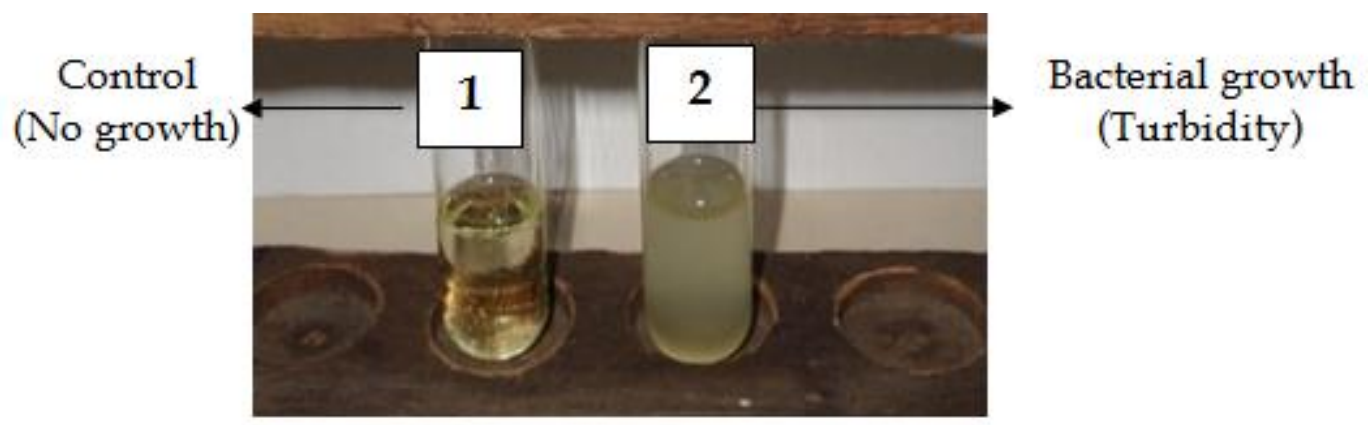

Figure 3. Growth of bacteria in nutrient broth indicated by turbidity $1=$ Control, $2=$ bacterial growth

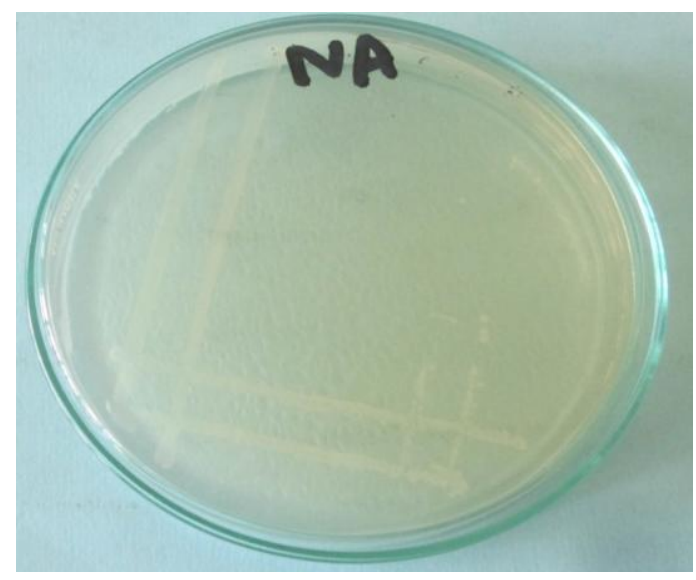

Figure 4. Salmonella colonies on Nutrient

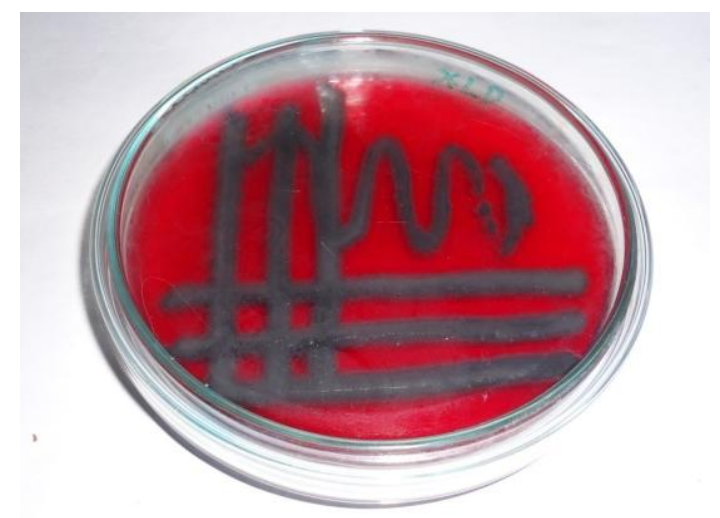

Figure 6. Salmonella colonies on XLD agar

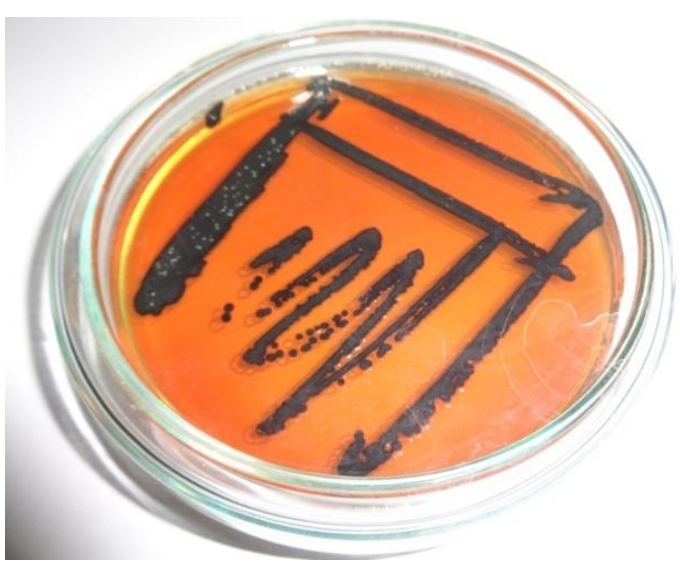

Figure 5. Salmonella colonies on S-S agar agar

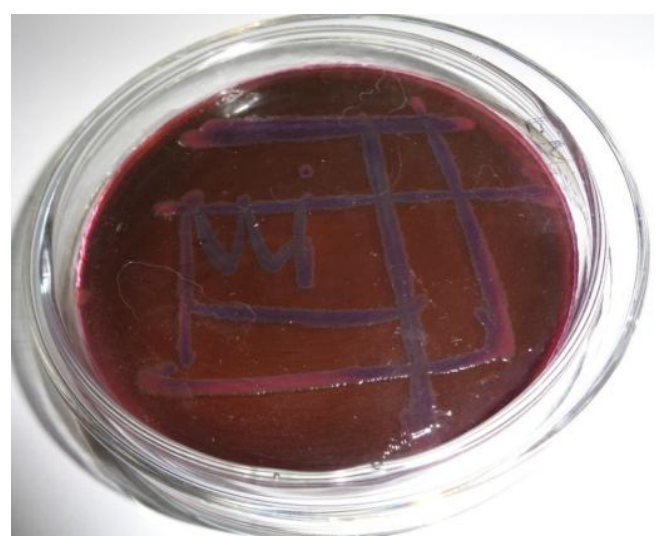

Figure 7. Salmonella colonies on EMB agar 


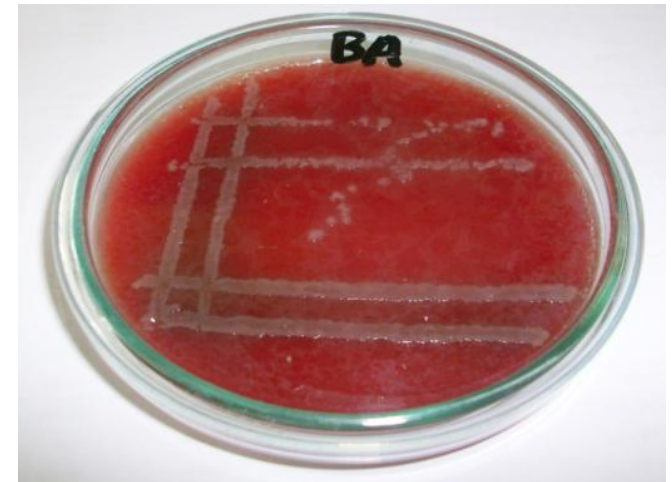

Figure 8. Salmonella colonies on Blood agar

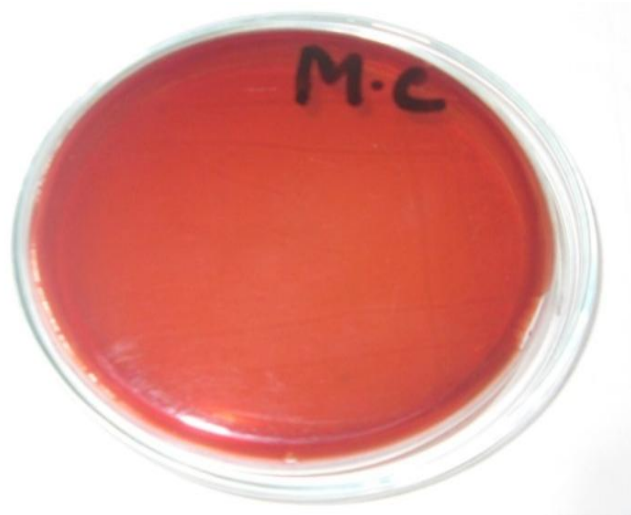

Figure 9. No growth of bacteria on MacConkey agar

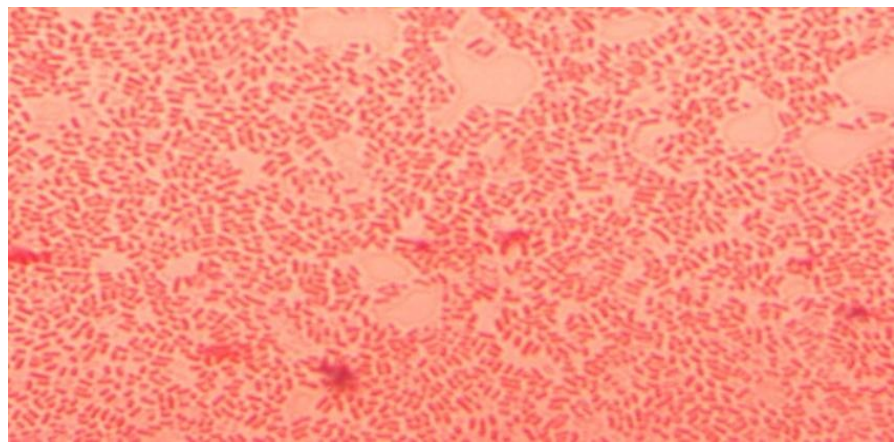

Figure 10. Gram staining of Salmonella isolates (100X)

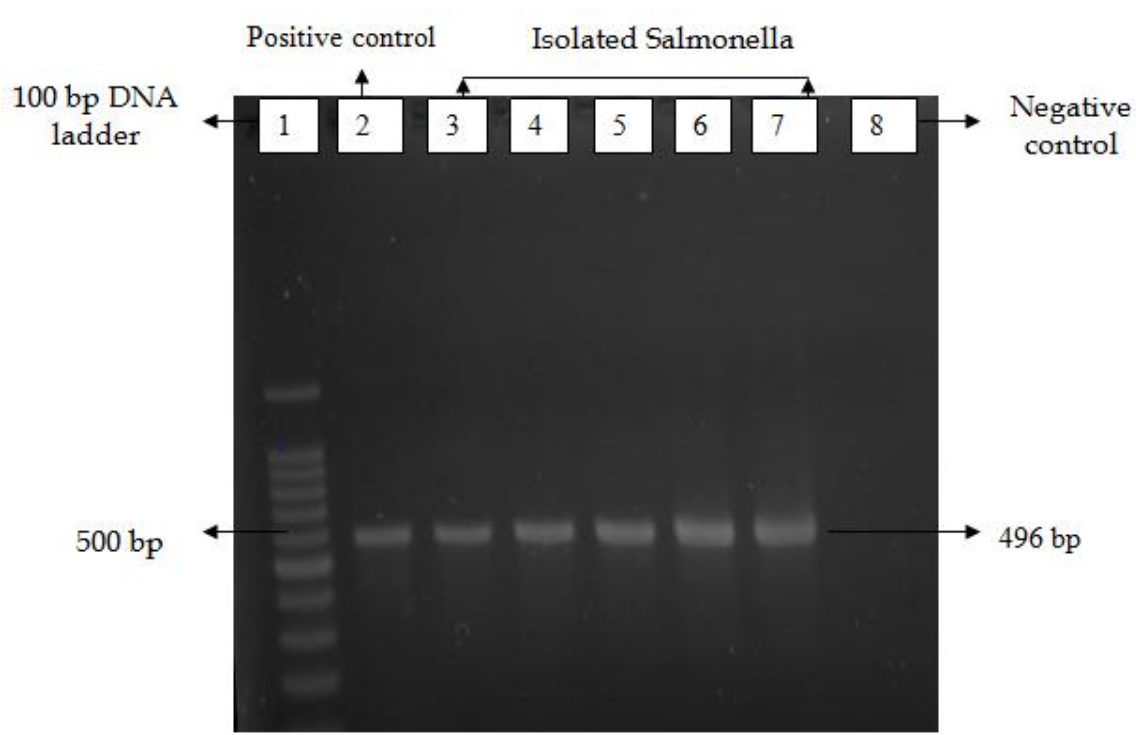

Figure 11. PCR image of Salmonella species Lane 1: 100 bp DNA ladder, Lane 2-Positive control, Lane 3-7: Isolated sample of Salmonella species and Lane 8: Negative control 
The present research work was selected and performed with the title 'Epidemiological Investigation on Duck Salmonellosis in some selected areas of Bangladesh" considering the specific objectives as the study of prevalence of duck salmonellosis based on age, sex, season and location differences following isolation, characterization using cultural, biochemical, molecular and antibiogram study. Infection by Salmonella is a common cause of food poisoning in humans (Hobbs and Robert, 1993). So, it is of great economic concern and public health significance. Isolation of Salmonella species from duck was reported in many other countries (Rettger et al., 1920) but there is no available report on prevalence of Salmonella species from duck and its comparison with those from other species in Bangladesh. For the study of prevalence at first data were collected through structured questionnaire from duck farmers and house hold duck keepers at selected areas of Bangladesh. On the basis of history and clinical signs and as per the information provided by the farmers the prevalence rate of Duck Salmonellosis was recorded as $38.1 \%$ and the $P$ value was calculated as $0.0003(\mathrm{p}<0.01)$ which was noted as highly significant.

Specific enrichment media and biochemical tests were used for the isolation and identification of Salmonella which was previously suggested by a number of researchers (Buxton and Fraser 1977; Mallinson et al., 1991; Ruiz et al., 1992; Sharma and Katock 1996; Dhruba et al., 1999; Habrun et al., 2006). In this study, colony characteristics of Salmonella from ducks of selected areas on MacConkey agar, SS agar, XLD agar and EMB agar were similar to the findings of other authors (Shaffer et al., 1964; Merchant and Packer, 1967; Buxton and Fraser, 1977). In Gram staining, the morphology of the isolated Salmonella exhibited Gram negative, small rod shaped, single or paired in arrangement under microscope which was supported by other researchers (Freeman, 1985; Gene, 2002). In motility test, all the isolates of Salmonella from duck have shown swinging movement which differentiates the motile Salmonella bacteria from non-motile and others (Merchant and Packer, 1967; Buxton and Fraser, 1977). Differentiation of Salmonella into species level was difficult to identify based on their sugar fermentation pattern (Freeman, 1985). In sugar fermentation test, all of the isolated Salmonella fermented dextrose, maltose and mannitol and produced acid and gas but did not ferment lactose which satisfies the statement of Buxton and Fraser (1977). Again, all the isolates were positive to methyl red test and negative to indole and V-P test (Buxton and Fraser, 1977).

The prevalence of Duck Salmonellosis in location parameters was recorded as $18.75 \%$ in Mymensingh, $16.67 \%$ in Lakshmipur, 34.61\% in Habiganj, 36.36\% Netrokona and 31.25\% in Kishoregonj. Overall prevalence rate of Duck Salmonellosis was recorded as $26.67 \%$. $P$ value was recorded as $0.0019(\mathrm{p}<0.01)$ which indicated that the result was highly significant (Table 4).

On the basis of cultural, biochemical and molecular confirmation the prevalence of Duck Salmonellosis was differed depending on different epidemiological parameters. Out of 120 fecal samples the prevalence of Duck Salmonellosis was $31.94 \%$ in 1 year aged ducks and $18.75 \%$ in more than 1 year aged ducks. $P$ value was calculated as $0.041(\mathrm{p}<0.05)$ that means the result was significant. Duck Salmonellosis was $10.52 \%$ prevalent in male birds whereas $34.14 \%$ were in female birds; and the $P$ value was calculated as $0.004(\mathrm{p}<0.01)$ which indicated the result was highly significant. Duck Salmonellosis was also prevalent $31.57 \%$ in Rainy season, $28.88 \%$ in summer and $18.92 \%$ in winter; and the $P$ value was calculated as $0.001(\mathrm{p}<0.01)$ that means the result was highly significant. At finally Duck Salmonellosis was prevalent $78.12 \%$ in sick birds and $7.95 \%$ were in healthy birds where $P$ value was calculated as $0.007(\mathrm{p}<0.01)$ which also indicate the result was reported as highly significant (Table 5).

On the basis history and clinical signs and as per the information provided by the farmers the prevalence rate of Duck Salmonellosis was recorded as $38.1 \%$ but after cultural, biochemical and molecular conformation it was revealed only $26.67 \%$ which showed similarity with the findings of other researchers (Snow et al., 2007; Limawongpranee et al., 1999). It also showed more or less similar results with other researchers who worked with cloacal samples of poultry. For instance, Haque (2011) isolated 48.07\% Salmonella from cloacal samples of apparently healthy ducks; Aktar (2011) found 59\% prevalence from cloacal swabs of quails and Sarkar (2009) recovered $20.83 \%$ from fecal samples and $75 \%$ from cloacal swabs of apparently healthy water birds. Conversely, Chiu et al. (2010) found $0.3 \%$ prevalence for cloacal swabs of breeder broiler and $11.3 \%$ for broiler, Mondal (2007) recorded prevalence of $13.07 \%$ from cloacal swabs of apparently healthy and diarrheic ducks. The differences among the prevalence percentages might be due to the species differentiation, hygienic, environmental and geographic variation and limitations in the laboratory of the study. 


\section{R. K. Dey and others}

In molecular characterization, a 496-bp band was seen in each lane with the product of the PCR for Salmonella species. The isolates of Salmonella species in this study were similar to the findings of the researcher (Noah et al., 1993).

In this study, total 5 isolates were investigated for susceptibility and resistance patterns by disc diffusion method using 5 commonly used antibiotics belonging to different criteria which were followed during sample collection such as age, sex, season, location and health status. The highest resistance was found with Oxacillin at all epidemiological criteria. This finding satisfy the result of Chugh and Suheir (1983), Banani et al. (2003), Lee et al. (2005), Kobayashi et al. (2007) and Haque (2011). Among 5 antibiotics the selected isolates showed 100\% sensitive to Ciprofloxacin and Azithromycin. On the other hand $80 \%$ were Intermediate to Tobramycin and Gentamycin and $100 \%$ were resistant to oxacillin which showed similarity with the findings of (Soomro et al., 2010). Notably the sensitivity and resistant pattern of the isolates against the 5 selected antibiotics were shown various results at different age, sex, location and season groups. Results of the study indicated that some isolates were more likely to be multi-drug resistant. Therefore, more sensible use of antibiotics can be strongly suggested for the veterinarians since drug resistance could be a major public health concern as fluoroquinolenes are important antimicrobial compounds in the treatment of Salmonellosis in humans (CLSI, 2012).

\section{CONCLUSION}

Results of this study concluded that Salmonella species was found to be an important cause of duck diseases in Bangladesh resulting significant economic losses through mortality, morbidity and reduced production. Epidemiological parameters were recorded as significant factors on Duck Salmonellosis in Bangladesh and the prevalence was varied in different age, sex, location, season and health status. Salmonella were successfully isolated and identified from the collected cloacal swabs from apparently healthy and diseased ducks by cultural, morphological, biochemical and molecular techniques. On the basis of history and clinical signs and as per the information provided by the farmers the tentative prevalence rate of Duck Salmonellosis was recorded as $38.1 \%$ and the $P$ value was calculated as $0.0003(\mathrm{p}<0.01)$ which was noted as highly significant but after cultural, biochemical and molecular confirmation it was revealed only $26.67 \%$ and the $P$ value was calculated as 0.0019 $(\mathrm{p}<0.01)$ which indicated that the result was highly significant. Antibiotic sensitivity was measured by their zone of inhibition and it might be suggested that ciprofloxacin and azithromycin could be used at any stage of duck rearing. Other drugs are not recommended for treatment and prevention of Salmonellosis at any stage of duck rearing. The isolated and characterized etiological agent of Duck Salmonellosis could be Salmonella anatum, Salmonella enteriditis, Salmonella enterica. The final and most important outcome of this study is the surveillance techniques of Salmonellosis in ducks of selected areas of Bangladesh were developed for the proper control and prevention of this economically important duck disease of the country.

\section{REFERENCES}

1. Aktar K (2011). Characterization of E. coli and Salmonella spp. from quail of selected farms in sadar upazilla of Mymensingh district, MS Thesis, Department of Microbiology and Hygiene, Faculty of Veterinary Science, Bangladesh Agricultural University, Mymensingh-2202.

2. Baki MA, Sarker AJ and Mondal MMH (1986). Pathological investigation on the mortality of ducks in Bangladesh, Bangladesh Agricultural University. Research Proceedings 1: 328-341.

3. Banani M, Pourbakhsh SA, Khaki P and Nikookhesal GH (2003). Serotyping and drug sensitivity of Salmonella isolates from commercial chickens and domestic pigeons submitted to Razi Institute. Pajouhesh-va-sazandegi-inAnimal-Sciences 59: 92-96.

4. Bauerfiend RS, Barth R, WeiB G and Baljer (2001). Haufigkeit des Salmonella-plasmid-Virulence-Gens "spvD” bei Salmonella-Stammen von Tieren. Dtsch. Tierarztl. Wochenschr.

5. Begum F (1992). Characterization of Salmonella isolated from apparently healthy and diarrhoeic ducks, MS Thesis, Department of Microbiology and Hygiene, Bangladesh Agricultural University, Mymensingh.

6. Buxton A and Fraser G (1977). Animal Microbiology. Blackwell Scientific Publications, Oxford, London, Edinburg, Melbourne. Volume1. pp. 85-86.

7. Cheesbrough M (1985). Medical laboratory manual for tropical countries. Volume 11 Microbiology. pp. 400-480.

8. Chiu LH, Chiu CH, Horn YM, Chiou CS, Lee CY and Yeh CM (2010). Characterization of 13 multi-drug resistant Salmonella serovars from different broiler chickens associated with those of human isolates. BMC Microbiology 10:86. 10.1186/1471-2180-10-86. 
9. Chugh TD and Suheir A (1983). Drug resistance among Salmonellae in Kuwait. Tropical and Geographical Medicine 35: 37-41.

10. Clinical Laboratory Standards Institute (2012). Performance Standards for Antimicrobial Susceptibility Testing; Twenty-second Informational Supplement. Wayne, PA: CLSI (Twenty-Two Informational Supplement M100S22).

11. Das PM, Rajib DMM, Monira N and Islam MR (2005). A retrospective analysis on the proportional incidence of poultry diseases in greater Mymensingh district of Bangladesh. Proceedings of the Seminar. $4^{\text {th }}$ International Poultry Show and Seminar 2005, 10-12 March, Bangladesh China Friendship Conference Centre, Dhaka, Bangladesh, World' Poultry Science Association, Bangladesh Branch. pp. 33-37.

12. Deighan T, Alwan A, Kelly J, McNair J, Warren T and O'Farrelly C (2000). Serum haptoglobin: an objective indicator of experimentally-induced Salmonella infection in calves. Research in Veterinary Science 69: 153-158.

13. Dhruba C, Chakrabory G and Chatterjee A (1999). Studies on avian salmonellosis in West Bengal. Indian Journal of Animal Sciences 69: 1-3.

14. Freeman BA (1985). Burrows textbook of Microbiology. W. B. Saunders Company, Philadelphia, London, Mexico City, Ro de Janerio, Sydney, Tokyo. pp. 464-472.

15. Gene O (2002). The isolation, identification and serotyping of Salmonella spp. isolated from domestic poultry in Kars district. Kafkas Universitesi Veteriner Fakultesi, Dergisi 8: 23-30.

16. Habrun B, Listes E, Spicic S, Cvetnic Z, Lukacevic D, Jemersic L, Lojkic M and Kompes G (2006). An Outbreak of Salmonella abortusovis. Abortions in Sheep in South Croatia. Journal of Microbiology 53: 286-290.

17. Haque ATM (2011). Investigation on Salmonellosis of geese population in sadar upazilla of Mymensingh district, MS thesis, Department of Microbiology and Hygiene, Mymensingh-2202.

18. Hobbs BC and Roberts D (1993). Food Poisoning and Food Hygiene, 6th Edition London: Edward Arnold.

19. Huque KS and Sultana N (2002). Study on the existing duck production systems in Bangladesh. A report of Bangladesh Livestock Research Institute, Bangladesh.

20. Islam MM (2007). Characterization of Salmonella isolated from apparently healthy and diarrhoeic calves, MS Thisis, Department of Microbiology and Hygiene, Bangladesh Agricultural University, Mymensingh.

21. Karim RM (2007). Investigation of sheep Salmonellosis in and around Bangladesh Agricultural University Campus, MS thesis, Department of Microbiology and Hygiene, Bangladesh Agricultural University, Mymensingh.

22. Kaura YK, Jagjit SR, Kidsbrestba X, Minakshi RC and Chaturvedi GC (1990). Salmonella gallinarum var. duishurg: An emerging biotype heavy mortality in poultry birds in northern India. Indian Journal of Animal Science 60: 127-130.

23. Kobayashi H, Kanazaki M, Shimizu Y, Nakajima H, Khatun MM, Hata E and Kubo M (2007). Salmonella isolates from cloacal swabs and footpads of wild birds in the immediate environment of Tokyo Bay. The Journal of Veterinary Medical Science 69: 309-311.

24. Kumar A and Kaushi RK (1988). Investigation of fowl typhoid in Haryana State. Indian Journal of Poultry Science 23: 104-106.

25. Kumar A and Kaushi RK (1988). Investigation of fowl typhoid in Haryana State. Indian Journal of Poultry Science 23: 104-106.

26. Lee YS, Han CH, Kang SH, Lee SJ, Kim SW, Shin OR, Sim YC, Lee SJ and Cho YH (2005). Synergistic effect between catechin and ciprofloxacin on chronic bacterial prostatitis rat model. International Journal of Urology 12: 383-389.

27. Limawongpranee SH, Hayashidani AT, Okatani K, Ono C, Hirota K, Kaneko and Ogawa M (1999). Prevalence and persistence of Salmonella in broiler chicken flocks. Journal of Veterinary Medical Science 61: 255-259.

28. Mallinson ET and Scherrer JA (1991). Xylose-lysine tergitol 4: An improved Selective agar medium for the isolation of Salmonella. Poultry Science 70: 2429-2431.

29. Merchant IA and RA Packer (1967). Veterinary Bacteriology and Virology. $7^{\text {th }}$ Edition, The Iowa State University Press, Ames, Iowa, USA.

30. Mondal T (2008). Isolation, identification and molecular characterization of duck Salmonella in comparison to Salmonella isolates of chicken and ruminants, MS Thesis, Department of Microbiology and Hygiene, Bangladesh Agricultural University, Mymensingh-2202.

31. Mustafa AHM, Miah MAH, Pandit KK and Hoque AFMH (1985). Isolation of Pasteurella anatipestifer from ducklings in Bangladesh. Bangladesh Veterinary Journal 19: 73-76. 


\section{R. K. Dey and others}

32. Noah DC, Holly LN, Edward DM, Howard WW, Robert WB, Pamela MR and Hargis BM (1993). Genus-specific detection of Salmonella spp. using the polymerase chain reaction (PCR). Journal of Veterinary Diagnosis and Investigation 5: 368-371.

33. Nooruzzaman M, Hoque E, Chowdhury EH and Islam MR (2012). Highly pathogenic avian influenza virus of clade 2.3.2.1 in quails and ducks in Bangladesh. Proceeding at BSVER ASCon XVIII, BAU, Mymensingh, February 2012. pp. 18-19.

34. Price JI and Berry LJ (1962). Salmonella infection in white Peking duck. Avian Diseases 6: 145-147.

35. Rahman MM (1977). Isolation and identification of Salmonella and Escherichia coli from river water, Pond water, tap water, tube well water and poultry feed, MS Thesis, Department of Microbiology and Hygiene, Faculty of Veterinary Science, Bangladesh Agricultural University, Mymensingh.

36. Rettger LF and Scoville MM (1920). Bacterium anatum (n. sp.). Journal of Infectious Diseases 26: 215-229.

37. Ruiz J, Sempere MA, Varela MC and Gomez J (1992). Modification of the methodology of stool culture for Salmonella detection. Journal of Clinical Microbiology 30: 525-526.

38. Sarkar MAH (2009). Identification of bacterial species isolated from apparently healthy water birds of Dhaka Zoo, MS Thesis, Department of Microbiology and Hygiene, Mymensingh-2202.

39. Sarker AJ (1980). Duck plague in Bangladesh. Indian Veterinary Journal 57: 787-791.

40. Sharma M and Katock RC (1996). Deadly outbreak in chicks owing to Salmonella typhimurium. Indian Journal of Poultry Science 31: 60-62.

41. Shaffer MF, Bridges JF, Clemmer DI and Pontoppidan KC (1964). Susceptibility of chicks to experimental injection with Salmonella typhosa. Animal Journal of Hydenburg 80: 377-387.

42. Snow LC, Davies RH, Christiansen KH, Carrique-Mas JJ, Wales AD, O'Connor JL, Cook AJC and Evans SJ (2007). Survey of the prevalence of Salmonella species on commercial laying farms in the United Kingdom. Veterinary Records 161: 471-476.

43. Soomro AH, Khaskheli M, Bhutto BM, Shah G, Memon A and Dewani P (2010). Prevalence and antimicrobial resistance of Salmonella spp. serovars isolated from poultry meat in Hyderabad, Pakistan. Turkish Journal of Veterinary and animal Sciences 34: 455-460.

44. Veling J, Zijderveld FG, Zijderveld-van Bemmel AM, Barkema HW and Schukken YH (2000). Evaluation of three newly developed enzyme-linked immunosorbent assays and two agglutination tests for detecting Salmonella enterica subsp. enterica serovar dublin infections in dairy cattle. Journal of Clinical Microbiology 38: 4402-4407. 